\title{
Contra el fundamentalismo
}

Miguel A. García

En diciembre de 2019, Dante Mantovani, presidente de la Fundação Nacional de Artes de Brasil, alimentó la narrativa discriminatoria pergeñada por el presidente ultraderechista Jair Bolsonaro mediante declaraciones que señalaban al rock como la causa del consumo de drogas y la puerta de acceso directo al sexo, al aborto y al "satanismo". ${ }^{1}$ Sus declaraciones, abonadas con referencias poco comprensibles a Herbert Marcuse, Theodor Adorno, John Lennon, la CIA y el gobierno soviético, ocasionaron un repudio rayano con el horror en los medios académico, intelectual y artístico, no solo por su contenido y la perspectiva desde la cual están conformadas, sino también por el hecho de que fueran proferidas por un funcionario supuestamente responsable de incentivar de manera plural la producción y el desarrollo de las artes y que, además, poseyera formación universitaria -según consta en su página de Internet, Mantovani ostenta títulos de grado y posgrado otorgados por la Universidade Estadual de Londrina-. ${ }^{2}$ Por varios motivos, sus declaraciones merecen una respuesta que vaya más allá de la aversión, en particular porque usurpan la autoridad que otorga el Estado, conferida por su cargo de funcionario, y la que concede la academia, atribuida por su condición de egresado universitario. Pero, ¿éstas deben ser descartadas o replicadas?

Las referencias condenatorias a las drogas, al sexo y al aborto inscriben las aseveraciones de Mantovani en una moral conservadora, y la alusión al "satanismo" las ligan a un pensamiento religioso que a priori reduce el fenómeno del rock a una lógica maniquea. Esta constatación despierta la duda en torno a si la perspectiva religiosa y su reduccionismo son motivos suficientes para descartar sus aseveraciones sin discusión o si, por el contrario, éstas deben ser atendidas e impugnarse su valor de

${ }^{1}$ Recuperado de https://www.youtube.com/watch?v=H0Xg1RnRM2Q

${ }^{2}$ Ver detalles en https://dantemantovani.org/wp/ 
"verdad" mediante la argumentación, la crítica o la evidencia, o rebatidas en algún otro término. Una forma de abordar esta duda consiste en asumir la política de la etnomusicología y la antropología cuando se enfrentan a conocimientos fundados en algún tipo de pensamiento religioso. Si estas disciplinas no han desvalorizado, ni mucho menos descartado, ese tipo de pensamiento cuando se manifiesta entre los pueblos originarios o los grupos urbanos subalternizados, en orden de ser coherentes, tampoco el carácter religioso de los dichos de Mantovani debería ser razón suficiente para desestimarlos a priori. Recordemos, además, que cuando un fundamento religioso ha tenido lugar en los desarrollos de las disciplinas sociales y humanísticas -particularmente en la filosofía-, éste ha dado lugar más a una refutación que a una desestimación sin réplica. También tengamos en cuenta que Mantovani pertenece a un medio en el cual la religiosidad tiene una presencia extendida a pesar de que muchos universitarios brasileros prefieran mantenerla al margen de las rutinas de investigación y otros se inclinen por no develar la importancia que ella ocupa en su trabajo académico. Tampoco el carácter reduccionista debería ser una razón válida per se para descartar sin réplica las aseveraciones de Mantovani. Acaso ¿no son en algún sentido reduccionistas la mayoría de las teorías sociológicas sobre el rock al excluir la dimensión sonora del fenómeno?

Otra posibilidad de estimar el grado de consideración que merecen las declaraciones de Mantovani es ponerlas en la órbita de las preocupaciones de una perspectiva ecléctica y en constante expansión que intenta desmarcarse de las políticas eurocéntricas y “epistemicidas” propagadas por los centros académicos del Norte. Según la versión más radical de esta perspectiva, la crítica decolonial conduce al reconocimiento de saberes habitualmente tachados como inconsistentes, religiosos, parciales o inferiores y, como resultado, a la conformación de un escenario plural y desjerarquizado. Las declaraciones que relacionan el rock con el "satanismo" ponen sobre el tapete una limitación del carácter radicalmente ecuménico de esta perspectiva: ¿cómo aceptar un saber que aun pronunciado desde los márgenes denigra una expresión musical de consumo masivo?, ¿cómo aceptar declaraciones que parecen ser reverentes con un conservadurismo que algunos creíamos aniquilado?, ¿cómo incluir declaraciones que excluyen, cierran universos y reducen la experiencia a una única variable?, ¿cómo convivir con una perspectiva que entrona un tipo religioso de moral y desecha el encanto de la duda y la multiplicidad hermenéutica? Si se trata de evitar un paternalismo indulgente o el subterfugio de la corrección política frente a la alteridad, la perspectiva inclusiva y descolonizada debe fijar un límite: no puede ofrecer un lugar acogedor 
a saberes que obliteran la diversidad de las prácticas y del conocimiento. No puede ofrecer un lugar acogedor a aseveraciones que celebran lo que ella misma viene a desplazar: el pensamiento único. En consecuencia, lo que debe ser refutado de las declaraciones de Mantovani no es tanto su contenido sino el mundo que prescriben, un mundo unidimensional, y la herramienta que lo diseña, el fundamentalismo. Es decir, sus declaraciones merecen más una respuesta política que denuncie el tipo de poder que encubren que un ardid musicológico o sociológico destinado a reivindicar una expresión musical o a denunciar la estrechez de la lente que la enfoca. 